\title{
TURNING POINT OF TURKISH-ARAB \\ RELATIONS: \\ A CASE STUDY ON THE HIJAZ REVOLT
}

NURI YEŞILYURT

\section{ABSTRACT}

This article aims at providing an historical analysis of the Hijaz Revolt (1916) which was led by the Emir of Mecca Sharif Husayn against the Ottoman Empire and which can be considered the turning point of Turkish Arab relations in the $20^{\text {th }}$ century. The main argument of this article is that although it opened a new phase in the course of Turkish - Arab relations and was marked as a traumatic moment in the social memory of the Turkish people, the Hijaz Revolt does not represent an overwhelming expression of an Arab or Islamic sentiment against the Ottoman Empire. It was rather a local reaction which took advantage of the general state of the Great War and the imperialist designs of the British in the Middle East, and which used the religion as an instrument to legitimise itself in the eyes of the Islamic world.

\section{KEYWORDS}

Hijaz Revolt, Turkish - Arab relations, World War I, the Ottoman Empire, British imperialism in the Middle East. 


\section{Introduction}

The Ottomans established their domination over many parts of the Arab Middle East and North Africa during the $16^{\text {th }}$ century. The main incentive for this domination was to maintain the security of the traditional spice route against the Portuguese attacks, which hindered the Eastern Mediterranean trade business considerably, and against which, the Mamluks were not powerful enough to resist. Despite not bringing a victory against the Portuguese in the Indian Ocean, the conquest of the Middle East and North Africa at least augmented the economic and military power of the Ottomans in the Mediterranean. There was also an ideological stimulus for these conquests. Ruling the predominantly Muslim Arabian lands -including the holy lands of Islam (haremeyn)- and controlling the institution of caliphate (khilafe) would definitely empower the Ottomans' claim for leadership in the Sunnite world, which would also be an asset while struggling against the Shiite Safavids in the East. Motivated by these ideological, military and economic factors, the Ottoman rule in the Arab Middle East and North Africa lasted for more than three hundred years despite many hindrances.

Dissolution of the Ottoman rule over the Arabian lands occurred as a gradual process during the $19^{\text {th }}$ and early $20^{\text {th }}$ centuries. The new owners of these territories were the imperialist powers, who were very much eager to find new markets and raw material sources for their rapidly growing national capitalist economies. By 1912, the whole North Africa had already been parcelled out among Britain, France and Italy, as if it was a prototype for the further partition of "the sick man of Europe", whose management had so far been among the most important factors in the maintenance of the European balance of powers.

By 1914, the remaining Arab territories under the Ottoman rule were roughly the Greater Syria (including Palestine and Lebanon), Iraq, Yemen and Hijaz; all of which to be lost hereafter. The First World War, therefore, symbolizes the last years of nearly four centuries co-habitation of the Turks and the Arabs within the same Empire. During this period, it was surely the Hijaz Revolt, besides the British military campaigns in Syria and Iraq, which paved the way for the defeat of the Ottoman Army in the Arab lands, and thus, the separation of these regions from the Empire. As it was an action 
performed, though not financed or equipped, by the Arab subjects of the Ottoman Empire, the Hijaz revolt poses a great significance at the turning point of Turkish - Arab relations. This significance, however, has tended to be ignored, research being focused on the role of Hijaz Revolt in the development of the Arab nationalism, and its importance for British war-time strategies in the Middle East. ${ }^{1}$ This article, thus, aims at providing an in-depth analysis of the Hijaz Revolt in order to have a better grasp of the circumstances and the dynamics that resulted in a break between the two peoples.

While concentrated on the Hijaz region during the war years, this article argues that it was, above all, the very practice of imperialism that triggered and financed the Hijaz Revolt against the Ottoman Empire. Thus, the major driving force of the revolt was an external factor. For the British, the idea of an Arab revolt was very much appealing since it would facilitate the advance of the British Army in Syria and Iraq, and thus, the eventual colonization of the region. Additionally, ruling a huge Muslim population in its colonies, the British Empire was certainly very much keen on supervising the Holy Lands of Islam, rather than leaving it to the indirect control of the "enemy Germans". Under these conditions, a struggle between the Ottomans and the British developed in the Hijaz in ordet to win over local tribes and leaders, a struggle which also fashioned Ottoman Arab relations in its final state.

The ideological stimulus of the Hijaz Revolt is another issue that has to be discussed in this work. While the Arabic national consciousness was developing as an intellectual movement during the $19^{\text {th }}$ century, the Hijaz, unlike Syria or Egypt, remained in a peripheral position in terms of intellectual activities. This peripheral position of the Hijaz did not change even after the 1908 revolution, when Arabism became a more politically-oriented movement within

${ }^{1}$ For instance, see Elie Kedourie, In the Anglo-Arab Labyrinth, Cambridge, Cambridge University Press, 1976; C. Ernest Dawn, From Ottomanism to Arabism Essays on the Origins of Arab Nationalism, Urbana, University of Illinois Press, 1973; Eliezer Tauber, Arab Movements in World War I, London, Frank Cass, 1993. One recent work which does focus on Ottoman - Arab relations during the war years is Hasan Kayal1, Arabs and Young Turks: Ottomanism, Arabism, and Islamism in the Ottoman Empire, 19081918, Berkeley, University of California Press, 1997. 
the Ottoman Empire. ${ }^{2}$ It seems, therefore, ironic that the most successful Arab reaction against the Ottomans during the war years came from the Hijaz. This article argues that, this irony strengthens the view that there was, if any, a very weak link between the idea of Arabism and the Hijaz Revolt, which is most evident from the latter's failure to attract even the Arab elements of the Ottoman Army completely. Moreover, while legitimising the revolt, its organizers adopted a religious discourse rather than nationalistic. This is not to say that the Hijaz Revolt was a religious reaction but just to stress the use of religion, in this case Islam, in justifying the revolt.

Taking stock of the economic and political context, laid down above, this article will analyse the war-time relations between the Ottomans and the Arabs in the Hijaz as a case study, and, will proceed as follows: In the first part, the political climate that led the Emir of Mecca Sharif Husayn to revolt against the Ottomans will be analysed. In this context, the evolution of the Ottoman policy in the Hijaz just before and after the outbreak of the Great War, along with the reaction of the Hijazis, will be explained. The second part will deal with the evolvement of the revolt plan of Sharif Husayn by analysing his contacts with various parties, including the British, the Ottomans and some Syrian notables. The third part will try to reveal the role of the idea of Arabism and Islam in the Hijaz Revolt, by taking a closer look at certain features of the revolt. In the last part, the Ottoman efforts to counter the revolt will be analysed.

\section{1 .}

Before the outbreak of the Great War, the Committee of Union and Progress (CUP), who had taken direct control of the Empire on 23 January 1913 with a coup d'état (Bâb-l Âli Baskını), seemed very keen on establishing and maintaining a firm central control over the remaining provinces of the crumbling Empire. Given its religious importance for now an overwhelmingly Muslim Empire, the Hijaz was definitely not exempt from the implementation of this

${ }^{2}$ For more information about the cities in which the idea of Arabism gained ground, see Rashid Khalidi, "Ottomanism and Arabism in Syria Before 1914: A Reassessment," in Khalidi, Rashid et.al., The Origins of Arab Nationalism, New York, Columbia University Press, 1991, pp. 54-61. 
centralisation policy. The appointment at the end of 1913 of a high ranking general, Vehip Paşa, the governor and commander of the forces in the Hijaz, instead of the previous government's candidate Nedim Paşa, was the first indication of the new government's unwillingness to further any form of autonomy in the region. ${ }^{3}$

Traditionally, regional authority in the Hijaz province was shared between Ottoman governors and Emirs of Mecca. Emirs were appointed by Ottoman Sultans among the prominent members of the House of Hashem, who were believed to be descendants of the Prophet Muhammad. They had three main functions in the Hijaz: firstly, they were responsible for the supervision and safety of the Muslim pilgrimage (hajj); secondly, they acted with the government to extend its political and military authority in the province and its environs; and thirdly, they accepted the overlordship of the Ottoman Sultans and accordingly legitimised the religious claims of the Caliph-Sultan as "the servant of the sacred places" (khadim alharemeyn ${ }^{4}$ Doubtful of the loyalty of the Emir of Mecca Sharif Husayn, who had been appointed to this position by the end of 1908 , and suspicious of his activities, Vehip Pașa set out energetically to enforce the CUP's centralization policy. As a result, the rivalry between the Emir of Mecca and the governor of the Hijaz came to a head.

The governor and the Emir clashed over various issues, the most important of which was the extension of the Hijaz Railroad from Medina to Mecca. Hijazi people were not in favour of the extension of the railroad. The Bedouins opposed it because it threatened their main livelihood, the camel rental, since pilgrims would prefer to travel by more convenient trains. ${ }^{5}$ In addition, the deployment of

\section{${ }^{3}$ Kayalı, Arabs, p. 17}

${ }^{4}$ William Ochsenwald, "Ironic Origins: Arab Nationalism in the Hijaz, 1882 1914," in Khalidi, Origins, pp. 190-191; Saleh Muhammad Al-Amr, The Hijaz Under Ottoman Rule 1869-1914: Ottoman Vali, the Sharif of Mecca, and the Growth of British Influence, Riyadh, Riyadh University Publications, 1978, p. 113; Selim Deringil, "Legitimacy Structures in the Ottoman State: The Reign of Abdulhamid II (1876-1909)," IJMES, Vol. 23 (3), 1991, p. 351

${ }_{5}^{5}$ Public Record Office (PRO), FO 141/460-8, from Abdul Kadir Mackawee in Aden to Wingate in Sudan, (25.02.1914); Ibid., from Kitchner in Cairo to 
Ottoman troops would be made easier, thus threatening the freedom of movement of the Bedouins in the Hijaz. The Emir opposed it for two main reasons. Firstly, he would come under direct control of the government as a result of the facilitation of transport between Syria and Mecca. The detachment of the sancak of Medina from the province of the Hijaz in 1910 and its new status as an autonomous sancak under the direct control of the imperial centre was viewed by the Emir as an outcome of the railroad, which had reached the town in $1908 .{ }^{6}$ Thus, he feared that the same would happen to the whole province if the railroad was extended to Mecca. Secondly, the impact of the railroad on the pilgrimage threatened the power that the Emir enjoyed through his control of the security of the pilgrimage route and also the income he derived from the camel rentals in which he had at least a $25 \%$ share. $^{7}$ Hijazi townsmen, too, opposed the extension of the railroad because of their fear of direct government control which might lead to local conscription and an increase in taxes. ${ }^{8}$ Moreover, a state of chaos, caused by the Bedouins protesting

Edward Grey (No. 58), (04.04.1914); Ibid., Secret note from British Agency in Cairo to FO, (19.04.1914). Since the agricultural activities and natural resources were very limited in the Hijaz, the region's economy was extremely dependent on the annual Muslim pilgrimage. The townsmen's main business was the accommodation and the maintenance of the pilgrims; whereas the tribesmen provided the transportation of the pilgrims by camel rental. Additionally, raiding the pilgrim caravans was another source of income for the tribesmen. A certain amount of money (urban sürresi) was paid annually by the Ottoman government to the Hijazi tribesmen in order to make them stop these raids and maintain the security of both the pilgrims and the wells on the pilgrimage route. Ochsenwald, "Ironic," p. 191; William Ochsenwald, "Ottoman Subsidies to the Hijaz, 1877-1886," IJMES, Vol. 6 (3), 1975, pp. 300-302; Murat Özyüksel, Hicaz Demiryolu, İstanbul, Tarih Vakfı Yurt Yayınları, 2000, pp. 67, 185-186.

${ }^{6}$ Özyüksel, Hicaz, p. 203; Kayalı, Arabs, 167-168.

${ }^{7} \mathrm{Al}-\mathrm{Amr}$, Hijaz, p. 79; PRO, FO 141/460-8, from Abdul Kadir Mackawee in Aden to Wingate in Sudan, (25.02.1914). The Emirs of Mecca also levied 3 liras from every pilgrim who landed at Jidda. Özyüksel, Hicaz, p. 197.

${ }^{8}$ The Hijaz had a special status within the Ottoman Empire that in the province, the local population was exempt from military conscription and various taxes, only the Islamic law ( $\operatorname{shari}^{\prime} a$ ) was applied in the courts, the slavery was permitted, and apart from the Ottoman Army, Emirs had their own guardians which were composed of voluntary Bedouins and freed 
against the railroad would affect the townsmen's pilgrim business badly. ${ }^{9}$

Other major area of conflict between the governor and the Emir was the former's attempts of drafting the black slaves to the Ottoman Army. ${ }^{10}$ Although the British Consul-General in Egypt reported to the Foreign Office in February 1914 that the "difficulties between Turks and Sharif of Mecca have been amicably settled,"11 the tensions had not in fact cooled. Hijazis showed their opposition to the policies of the government in various ways. Emir Husayn wired several times to İstanbul and urged the deposition of Vehip Paşa. The governor, in turn, corresponded with İstanbul complaining about Sharif Husayn. ${ }^{12}$ Consequently, unrest broke out in the region and the Bedouins closed the road from Jidda to Mecca. ${ }^{13}$

As a result of this agitation, and anxious about the initial contacts between the Sharifian family and the British, the CUP was compelled to abandon its firm centralization measures in the province. A decree issued in March 1914 stated that no changes would be made to the status quo in the Hijaz. ${ }^{14}$ However, the state of affairs in the region remained strained until late 1914. Although Vehip Paşa continued to write reports to İstanbul until August 1914 in which he reiterated his accusations against Sharif Husayn on

slaves. Özyüksel, Hicaz, p. 185; Ochsenwald, "Subsidies," p. 301 Ochsenwald, "Ironic," pp. 194-195; Kayalı, Arabs, pp. 154-156.

9Ochsenwald, "Ironic," p. 191; Özyüksel, Hicaz, pp. 185-186.

${ }^{10}$ C. Ernest Dawn, "The Amir of Mecca al-Husayn ibn-'Ali," in Dawn, From Ottomanism, pp. 16-18; Kayalı, Arabs, pp. 182-183; Ochsenwald, "Ironic," p. 195.

${ }^{11} \mathrm{PRO}$, FO 141/460-8, from Consul-General in Cairo to FO, (14.02.1914).

${ }^{12}$ Kayall, Arabs, p. 182. The correspondence between Sharif Husayn, Vehip Pașa and İstanbul was reproduced without any references in Feridun Kandemir, Peygamberimizin Gölgesinde Son Türkler: Medine Müdafaasl, İstanbul, Yağmur Yayınları, 1999, pp. 352-356.

${ }^{13} \mathrm{PRO}, F O$ 141/460-8, from Consul-General in Cairo to FO (No.20), (21.03.1914).

${ }^{14}$ Dawn, "Amir," p. 17. A member of the Sharifian family told the British that the governor "had to kiss [the] hand of Huseyin publicly" after the CUP's compromise. PRO, FO 141/460-8, from G. H. Symes to HC in Cairo (No. 70/84-1198), (05.08.1915); Kayalı, Arabs, pp. 182-183. 
various matters, urged his deposition and called for the reinforcement of the military force in the province, the government always replied urging rapprochement with the Emir and maintenance of the status quo in the region. ${ }^{15}$

After the Ottomans' entry into the Great War, the government policy in the Hijaz aimed at maintaining active support of the Emir of Mecca. This support consisted of despatching a voluntary Bedouin force for the Canal Campaign and the Emir's endorsement of the Ottoman Sultan's call for jihad. Hijazi Bedouins' participation in the Canal Campaign was deemed very important by the Commander of the Fourth Army Cemal Paşa since it would improve the motivation of the Ottoman troops and mean the Emir's de facto approval of the jihad. According to Cemal Paşa, when he requested from Sharif Husayn a voluntary force for the First Canal Campaign by late 1914, the latter "politely" accepted this request and despatched a Bedouin force under the command of his eldest son, Sharif "Ali, along with the governor Vehip Pasa, who also proceeded to the north in order to join the campaign. ${ }^{16}$ Sharif 'Ali, however, got no further than Medina where he stopped because one of his men had reportedly seized the suitcase of a well-known CUP member which contained secret correspondence between Vehip Paşa and İstanbul regarding plans to depose Sharif Husayn and abolish the special status of the Hijaz. ${ }^{17}$ After this revelation, Sharif Faysal, the son of Sharif Husayn, made contacts with CUP leaders in İstanbul in the spring of 1915 and insisted on the recall of Vehip Paşa. ${ }^{18}$

Cemal Paşa's insistence on the support of the Hijazi volunteers continued during the preparations for the Second Canal Campaign as well. In response to this insistence, Sharif Husayn cabled Enver on 10 July 1915 reassuring him of his loyalty to the cause of jihad, reiterating the fragility of the Hijaz's war-time situation which required careful handling, and requesting arms and money for the

${ }^{15}$ Kayal1, Arabs, pp. 182-183.

${ }^{16}$ Cemal Pașa, Hatırat, İstanbul, Arma Yayınları, 1996, pp. 161-162.

${ }^{17}$ Dawn, "Amir," pp. 27-28.

${ }^{18}$ Eliezer Tauber, Arab Movements in World War I, London, Frank Cass, 1993, p. 63. Subsequently, Galip Pașa was appointed the new governor of the Hijaz. He arrived in Mecca on 6 June 1915. 
mobilization of the Hijazi volunteers for the Second Canal Campaign. The government, keen on maintaining the support of Sharif Husayn, accepted the request and gave money and arms to Husayn for the mobilization of volunteers. ${ }^{19}$ Finally, as a response to the increasing Ottoman insistence, Husayn sent Sharif 'Ali to Medina with 1,500 Bedouin forces in order to proceed to Syria and join the campaign. However, these forces too remained in Medina for an extended period and a conflict started to develop between the muhafiz of Medina Basri Paşa and Sharif 'Ali. ${ }^{20}$

Despite Ottoman desires, the population of the Hijaz had no interest in supporting any action hostile to the British since any such action would threaten their security and economic position. The dramatic decrease due to the war in the number of the pilgrims coming from the Allied colonies such as India and North Africa had already brought the main economic activity in the Hijaz to a halt and caused the Hijazis to "curse the war and those who caused it". ${ }^{21}$ Additionally, the supremacy of the British navy in the Red Sea constituted a great threat to the Hijazis in the event of their support of any hostile action against the British, so that a trade blockade that could be exerted by Britain on the Hijaz coasts would have had disastrous consequences for the region. ${ }^{22}$ Consequently, this fragile situation in the region gave Sharif Husayn a useful reason for not

${ }^{19}$ Kayal1, Arabs, p. 192. Three months later, Sharif Faysal stated to the British that "they have no intention to fight for Turks" and if they were sent to the Canal Campaign, their actions would only be pretence. PRO, FO 141/461-1, from HC in Cairo to FO (No. 626), (20.10.1915).

${ }^{20}$ Tauber, World, pp. 78-79; Dawn, "Amir," pp. 33-34; Yusuf Hikmet Bayur, Türk İnklâbı Tarihi, Vol. III/3, Türk Tarih Kurumu Basımevi, 1957, pp. 254-258.

${ }^{21}$ PRO, FO 141/460-8, Letter from Sharif Husayn to Ronald Storrs via messenger Mohammed Ibn Arif Ibn Oreifan in Alexandria, (18.08.1915). See also T. E. Lawrence, Seven Pillars of Wisdom: A Triumph, London, Jonathan Cape, 1990, p. 25.

${ }^{22}$ Britain did not exert a trade blockade on the Hijaz coasts until 15 May 1916 and this policy predictably created sympathy towards the British among the Hijazis. See PRO, FO 141/460-8, Letter from Sharif Husayn to Ronald Storrs via messenger Mohammed Ibn Arif Ibn Oreifan in Alexandria, (18.08.1915); PRO, FO 141/461-2, from McMahon in Cairo to Edward Grey, (10.05.1916). 
participating in any hostile actions against the British as well as for not approving or promoting the Ottoman Sultan's call for jihad.

2.

In this political climate, Sharif Husayn calculated his advantages well and decided to find a solution for the Hijaz outside the Ottoman framework. His contacts with the British and with some Syrians were of great importance in the formulation of his new policy towards the Ottomans. On the basis of the available evidence, it can be argued that he had decided to break with the Ottomans before the outbreak of the Great War, as early as February 1914, while the centralization measures of the CUP were mounting in the Hijaz. However, after the suspension of the centralization measures in March 1914 and the subsequent recall of Vehip Paşa, the tide of events, particularly the outbreak of the war, gave Sharif Husayn the finest opportunity to strengthen his ties with Britain in order to gain his independence from the crumbling Ottoman Empire. Accordingly, Sharif Husayn's decision to break with the Ottomans should not be considered exclusively related to the CUP's centralization policy, which had been suspended in the Hijaz in March 1914, but to the current political climate in which Husayn calculated his best interests as being with the British.

Anglo-Sharifian contacts started in February 1914 in Cairo between Sharif 'Abdallah, son of Sharif Husayn, and Lord Kitchener, the British High-Commissioner in Egypt. In this meeting, 'Abdallah complained about the new governor of the Hijaz Vehip Paşa, "who is not in sympathy with the people and who does not act harmoniously with his father in the conduct of internal affairs of the holy places as well as comfort and security of Moslem pilgrims coming from all over the world." He asked "whether in case this friction become [sic] acute and an attempt made by the Turkish government to dismiss his father from his hereditary office of Sharif of the holy places, you [the British] would use your good offices with the Sublime Porte to prevent any such attempt?" 23 This is the first documented overture of

${ }^{23} \mathrm{PRO}, \mathrm{FO}$ 141/460-8, from Kitchener in Cairo to Edward Grey (No. 22), (06.02.1914). 'Abdallah further hoped that the British Government would not allow reinforcements of the Ottoman forces to be sent by sea in the 
the Sharifian family to the British for direct assistance against the Ottomans since the appointment of Vehip Paşa as the governor of the Hijaz.

Up to December 1914, the correspondence between the Sharifs and the British developed in a positive and encouraging manner for both sides. In September 1914, Kitchener wanted Storrs to ascertain from Sharif 'Abdallah whether "should present armed German influence at Constantinople coerce Khalif against his will and Sublime Porte to acts of aggression and war against Great Britain he and his father and Arabs of Hejaz would be with us [Britain] or against us."24 "Abdallah, in his reply to the British, stated that he desired closer union with Britain but expected written promises that Britain would abstain from internal intervention in Arabia and guarantee the Emir against foreign and Ottoman aggression. ${ }^{25}$ Kitchener's response was that "if the Amir and Arabs in general assist Great Britain in this conflict that has been forced upon us (by) Turkey, Great Britain will promise not to intervene in any manner whatsoever whether in things religious or otherwise. Moreover recognising and respecting the sacred and unique office of the Amir Hosayn, Great Britain will guarantee the independence, rights and privileges of the Sharifate against all external foreign aggression, in particular that of the Ottomans." 26 Sharif "Abdallah replied to these pledges that his father had no intention of adopting a policy hostile to British interests, while Sharif Husayn himself, in a verbal message, stated that his position in the world of Islam and the present political situation in the Hijaz made it impossible for him to break with the Ottomans immediately, though he was waiting for a suitable pretext. ${ }^{27}$ At the same time, Emir Husayn reported to the British that

event of a quarrel and asked if Edward Grey could send a supportive message to Sharif Husayn, but Kitchener answered that "it would be improbable." Idem.

${ }^{24}$ Ibid., from FO to Consul-General in Cairo (No. 219), (24.09.1914).

${ }^{25} \mathrm{Ibid}$., from Consul-General in Cairo to FO (No. 233), (31.10.1914).

${ }^{26} \mathrm{Ibid}$., from FO to Consul-General in Cairo (No. 303), (31.10.1914), (Attached letter to 'Abdallah).

${ }^{27}$ Ibid., from Consul-General in Cairo to FO (No. 303), (10.12.1914). 
through his political influence, "rebellion and disobedience had well nigh broken out among the Syrian corps." 28

In the spring of 1915, Sharif Faysal held secret meetings with some Syrian notables, including Fawzi al-Bakri, Nasib al-Bakri and Shukri al-Ayyubi, who presented him with the Damascus Protocol in which the boundaries of the independent Arab country, to be demanded from the British, were laid out and a petition to Husayn approving his cooperation with the British. ${ }^{29}$ Faysal, highly satisfied with the readiness of Syria for cooperation in the planned revolt, returned to Mecca on 20 June 1915 and handed the Syrians' proposal to his father. The overture of the Syrian notables to Husayn had two meanings for the latter. Firstly, their support would increase the possibility of success of the planned revolt which could not be carried out solely with the man-power of the Hijaz and would accordingly increase his credibility in the eyes of the British. Secondly, the boundaries of the independent Arab country in the Damascus Protocol had great appeal for the Sharifian family and exceeded their territorial expectations which had until now been limited to a kingdom in the Hijaz and its environs. Thus close contact with the Syrians was very much in the interest of Sharif Husayn.

Having gained the support of the Syrians, Husayn was now ready to resume negotiations with Britain in order to reach a final agreement and secure their support against the Ottomans. On 14 July 1915, Husayn started negotiations with Henry McMahon, the British High-Commissioner in Egypt. ${ }^{30}$ Negotiations lasted until 30 January

${ }^{28} \mathrm{Ibid}$., a note taken by messenger $\mathrm{X}$ on a discourse by Sharif of Mecca, (09.12.1914).

${ }^{29}$ Tauber, World, pp. 62-65; George Antonius, The Arab Awakening, London, Hamish Hamilton, 1938, pp. 152-158; Lawrence, Seven, pp. 2629. The boundaries were laid out as: "North: The line Mersin-Adana to parallel $37 \mathrm{~N}$. and thence along the line Birejik-Urfa-Mardin-MidiatJazirat(Ibn 'Umar)-Amadia to the Persian frontier; East: The Persian frontier down to the Persian Gulf; South: The Indian Ocean (with exclusion of Aden, whose status was to be maintained); West: The Red Sea and the Mediterrenean Sea back to Mersin." Antonius, Awakening, p. 157.

${ }^{30}$ The original documents of the correspondence can be found in PRO, FO $141 / 461-1 ;$ FO 141/461-2. 
1916, and in the end, Britain complied with the territorial demands of Sharif Husayn with some exceptions. ${ }^{31}$

In early January 1916, just before the conclusion of an agreement with the British, Husayn sent his son Faysal to Syria in order to make the last arrangements for the rebellion. Faysal, however, found the situation in Syria desperate as a result of firm security measures applied by Cemal Paşa in the region. Under these circumstances, Faysal viewed an action of rebellion unfeasible, and therefore, urged his father to postpone it. ${ }^{32}$ Subsequently, Husayn reported to McMahon that "Syria can neither engineer revolution nor seize Hijaz Railway owing to dispersal of Chiefs." 33 The British, being suspicious of Faysal's sincerity to the cause of revolt, ${ }^{34}$ and, anxious about his action plans in Syria that would endanger the interests of the French, suggested that Husayn "confine himself to securing the railway and clearing the Turks out of Hijaz." 35

In April 1916, Sharif Husayn cabled to Enver Paşa and demanded the recognition of his hereditary rule in an autonomous Hijaz, from Tebbuk to Mecca, declaration of an amnesty in Syria and Iraq, particularly those sentenced to death in a court martial in 'Aleyh, and suggested that once these demands were met he would then despatch the Bedouin forces under Sharif 'Ali from Medina to

${ }^{31}$ The exceptions were: Mersin and İskenderun; the portions lying west to the districts of Damascus, Homs, Hama and Aleppo, and, the provinces of Basra and Baghdad. Ibid., from HC in Cairo to FO, (26.10.1915); PRO, FO 141/461-2, from HC in Cairo to FO, (30.11.1915).

${ }^{32}$ Tauber, World, p. 78; Antonius, Awakening, p. 188.

${ }^{33} \mathrm{PRO}, \mathrm{FO} 141 / 461-2$, from HC in Cairo to FO (No. 272), (18.04.1916).

34"Faisal has been and is in great touch with Enver who is a strong character and offered a handsome money to Faisal to fight on his part. We are also asked to provide money for the same force which is pledged to subsequently be used against the Turks. How can we be sure that this force is not going to be used against us? We can trust Sheriff but not Faisa because of the possibility that he is playing for his own hand." Ibid., from Clayton to Governor-General in Erkowit (No. 299), (22.04.1916).

${ }^{35}$ Ibid., from Governor-General in Khartoum to Clayton in Cairo (No. 448), (23.04.1916); Ibid., from HC in Cairo to FO (No. 387), (24.05.1916). 
Syria in order to join the Second Canal Campaign. ${ }^{36}$ Considering the crucial state of the war for the Ottomans, Husayn's telegram can only be described as an attempt to find a "pretext" for his planned rebellion. Nevertheless, the Ottoman authorities do not seem to have been interested in taking any preventive actions over the suspicious activities of Sharif Husayn. Instead, İstanbul was content with merely urging him to recall Sharif "Ali to Mecca and threatening that he would not see his other son Sharif Faysal, who was in Syria at that time, until the despatch of the Bedouin forces to Syria. ${ }^{37}$ During the subsequent correspondence between Husayn and İstanbul, the conciliatory policy of the Ottomans towards Husayn continued, so that in the end, instead of taking preventive actions, they came into an understanding with Husayn that Sharif Faysal would go back to Medina to fetch the Bedouin volunteers; as soon as he arrived in Medina, Sharif 'Ali would return to Mecca, and, after the arrival of the Bedouin forces in Syria, the issue of amnesty would be considered by Cemal Paşa. ${ }^{38}$

Shortly after Faysal's arrival in Medina, Sharif Husayn cabled to Cemal Paşa and Grand Vizier Sa id Halim Pasa that since he did not know whom he should rely on among two Ottoman officials, one very courteous (Enver) other very rude (Cemal), he had to cease his relations with the government and pull his sons back to Mecca until he received a satisfactory answer to his telegram which was sent to Enver Paşa in April 1916. ${ }^{39}$ Finally, the Sharifs, taking advantage of the pacifying policy of the Ottomans, were able to start their revolt on 6 June 1916 in Medina. Then, Sharif Husayn officially proclaimed his revolt on 10 June 1916 in Mecca. 40

${ }^{36}$ Bayur, Türk, p. 248; Cemal Pașa, Hatırat, pp. 261-262; Dawn, “Amir," pp. 34-35.

${ }^{37}$ Dawn, “Amir," p. 35; Tauber, World, p. 80.

${ }^{38}$ Dawn, "Amir," pp. 36-38; Tauber, World, p. 80. Cemal Pașa describes Faysal's feelings that his "eyes started to scatter sparks of joy" when he heard from Cemal that he was allowed to go back to Medina in May 1916. Cemal Paşa, Hatırat, p. 270.

${ }^{39}$ Cemal Paşa, Hatırat, p. 274.

${ }^{40}$ Sharifian forces captured Mecca on 9 July 1916, Jidda on 16 July 1916 , Taif on 22 September 1916, Yanbo on 31 September 1916, Al-Wajh on 26 January 1917 and Aqaba on 6 July 1917. İzzettin Çopur, "Hicaz Filistin ve Suriye Cephesindeki Arap Ayaklanması, Bu Ayaklanmada İngiliz 
3.

Although Sharif Husayn's revolt led to the events that resulted in a total break between the Turks and the Arabs, it cannot be considered a reaction of the Arabs as a whole against the Ottoman Empire. It was rather a local reaction with the support of an external power. The extent to which the revolt was a local affair, driven largely by one man's ambitions rather than by any wide-appeal idea of Arabism can be seen in the limited range of Sharif Husayn's influence which stretched only to the Hijaz and, to a smaller extent, its environs, and, was extremely dependent on British support. According to a British intelligence officer, Sir Wyndham Deedes, Sharif Husayn was not recognised as a very powerful figure in the other Arab lands and it is impossible for Syrians, Yemenis and Iraqis to be under the rule of one chief even if they may acknowledge one spiritual chief. ${ }^{41}$ Moreover, a contemporary British report suggests that the people of Mecca were almost pro-Ottomans and those on the side of Sharif Husayn were about 5,000 people among whom the men of influence were about $500 .^{42}$

The lack of enthusiasm among the Arab elements of the Ottoman Army about the revolt was also a sign of the local character of Sharif Husayn's movement. Arab prisoners of war, who were sent to prisoner camps in India and Egypt, were viewed by the British and the Sharifs as potential conscripts to the revolting army. This method, however, had little success because the overwhelming majority of the

Lawrence'ın Rolü," Stratejik Araştırma ve Etüt Bülteni, Vol. 1 (1), 2001, pp. 205-211; PRO FO 141/461-3, from HC in Cairo to FO, (31.07.1916). The city of Medina, despite numerous hindrances, strongly held out under the command of Fahreddin Pasa until 7 January 1919, two months after the Mondros Armistice. A circular of Fahreddin Paşa, instructing the soldiers the methods of eating locusts, demonstrates the hard conditions that Medina suffered during the revolt. Kandemir, Peygamberimizin, pp. 123$125,181$.

${ }^{41}$ Zeine N. Zeine, Arab-Turkish Relations and the Emergence of Arab Nationalism, Beirut, Khayat's, 1958, pp. 105-106.

${ }^{42} \mathrm{PRO}$, FO 141/817-9, from McMahon in Cairo to Viscount Grey (No. 297), (03.10.1916). 
prisoners refused to take any action against the caliphate and feared being shot immediately if caught by the Ottomans. ${ }^{43}$

Arab deserters from the Ottoman Army were also viewed as a valuable source of soldier and officer by Sharif Husayn. According to Tauber, "from about a million soldiers in 1915, half had deserted by the end of the war." 44 The number of Arab deserters was very high in Medina as well, so that Fahreddin Paşa ordered on 7 April 1918 that captured deserters be shot and those who caught them be granted fifteen gold liras. ${ }^{45}$ The high number of Arab deserters, however, did not necessarily mean that all of those deserters fought on Sharif Husayn's side. In contrast, most of them preferred to return to their homes or hide from their Ottoman pursuers until the end of the war. ${ }^{46}$ Furthermore, some Baghdadi officers, who had deserted to the Sharifian forces, posed great problems for both the Sharifs and the British. In some British reports, they were accused of being proTurkish and working only for their own economic interests by stealing the money and the stores sent by the British to the revolting army. It was claimed that they were doing tremendous harm "in the Hedjaz by starting all that was bad in the former Turkish rule," and also in the prestige of Husayn among the Bedouins. ${ }^{47}$ Moreover, they were accused of hindering any sort of action against the Ottomans by breaking the guns. ${ }^{48}$ In this sense, they were also suspected of being Ottoman agents. ${ }^{49}$

43Tauber, World, pp, 102-110; Orhan Koloğlu, Bedevi, Lavrens, Arap, Türk, İstanbul, Arba Yayınları, 1993, p. 114; Édouard Brémond, Le Hedjaz dans la Guerre Mondiale, Paris, Payot, 1931, pp. 87-88

${ }^{44}$ Tauber, World, p. 111.

${ }^{45}$ Naci Kâșif Kıcıman, Medine Müdafaası, Hicaz Bizden Nasıl Ayrıldı?, İstanbul, Sebil Yayınevi, 1971, p. 193.

${ }^{46}$ Tauber, World, p. 111.

${ }^{47} \mathrm{PRO}$, FO 686/52, from Davenport in Jidda to Colonel Bassett in Jidda, (25.04.1918). See also Ibid., from Colonel Wilson in Jidda to Arab Bureau in Cairo (No. 12/16/Misc), (18.07.1918); Ibid., from Hussein Nuri al-Kueri to Colonel Bassett, (28.05.1918).

${ }^{48} \mathrm{Ibid}$., from Davenport to Garland, (30.05.1918); Ibid., from M.Kaisuni in Mecca to Colonel Wilson in Jidda, (30.06.1918).

${ }^{49}$ Ibid., from Davenport at sea to Wilson in Jidda, (16.06.1918). Apart from these, a conflict developed between the Iraqi and the Syrian officers in the revolting army because the latter felt themselves discriminated in favour of 
Notwithstanding the high number of deserters, there were many Arab officers serving in the Ottoman Army until the end of the war. ${ }^{50}$ Yasin Hilmi (al-Hashimi), a member of $A l$-'Ahd, ${ }^{51}$ commanded the $24^{\text {th }}$ Division in Palestine front near Tul Karm in 1918 and was then appointed the commander of the $8^{\text {th }}$ Army-corps stationed in Salt in Transjordan. He refused numerous offers from Sharif Faysal to join the rebellion. His brother Major Taha was the Chief of General Staff in the $7^{\text {th }}$ Ottoman Army-corps in Yemen and served for the Ottomans until the end of the war. Likewise, Captain Mehmed Bey commanded the Ottoman forces in Ma'an and served during the Hijaz Revolt. ${ }^{52}$ "To most of them" says Lawrence referring to the Al- 'Ahd members, "the word was never given; for those societies pro-Arab only, willing to fight for nothing but Arab independence; and they could see no advantage in supporting the Allies rather than the Turks, since they did not believe our assurances that we would leave them free." 53

Another feature of the Hijaz Revolt was its absolute reliance on the Bedouins, the nomadic people living autonomously in deserts. They formed $75 \%$ of the Hijaz population ${ }^{54}$ and had always been out of the direct control of the government. Since the main motivation in their actions was economic rather than religious, ${ }^{55}$ the support of the

the Iraqis who took over all the senior positions. Idem.; Tauber, World, p.

${ }^{50}$ On this issue, Dawn suggests: "Many Arab officers, served at the Straits or in the Caucasus. Others, however, served in Palestine; even here, recruits for the Arab army appeared to have been prisoners of war more often than deserters." C. Ernest Dawn, "The Rise of Arabism in Syria," in Dawn, From Ottomanism, p. 157

${ }^{51}$ Al-Jam'iyya al- 'Ahd (Covenant Society) was formed on 28 October 1913 in İstanbul as a secret society by Aziz 'Ali al-Misri, an Arab officer in the Ottoman Army. Its membership included Arab officers exclusively.

${ }^{52}$ Tauber, World, pp. 115-116; Ali Fuat Erden, Birinci Dünya Harbinde Suriye Hatıraları, İstanbul, İş Bankası Yayınları, 2003, pp. 89-90.

${ }^{53}$ Lawrence, Seven, p. 23.

${ }^{54}$ Brémond, Hedjaz, p. 14

55"They [the Bedouins] are by no means fanatically religious contrary to the received idea; they neither fast nor pray, and in reality are only nominal Mohammedans" A. J. B. Wavell, A Modern Pilgrim in Mecca and a Siege 
Bedouins during the revolt rested on two major factors: money and military power. Both Sharif Husayn and the Ottomans fought to win over them, but in the end it was the party which paid more money, contributed more grain and demonstrated greater power which secured Bedouin support. It seems, therefore, disputable that the Bedouins were motivated by nationalist aspirations or religious sentiments. It was rather some short-term economic calculations that drove most of them against the Ottomans.

Sharif Husayn's forces, with the exception of ex-Ottoman officers who joined the rebels after the outbreak of the rebellion, were almost entirely made up of Bedouins. ${ }^{56}$ The financial contribution of Britain was essential for Husayn to win over the Bedouins. In August 1915 , a famous member of the Sharifian family expressed to the British that Sharif Husayn's good relations with the Arabs of desert was dependent on his money and grain contribution to them, and thus, British contribution to Husayn in terms of money, grain and arms was essential for Husayn's consolidation of power in Arabia. ${ }^{57}$ Britain provided gold and foodstuff to the Bedouins mainly via Sharif Husayn. In September 1916, McMahon urged Sharif Husayn that "he should endeavour to counteract the influence of Turkish gold among the Arab tribes by more generous payments on his own part." 58 The source of these "generous payments" was predictably the British.

Despite the fact that Islam was not the major driving force in the actions of the Bedouins, who were the most important contingent of the revolting army, it was definitely the main pillar of Sharif Husayn's propaganda. Sharif Husayn commenced his religious

in Sanaa, London, Constable \& Company, 1912, p. 59. See also Kıcıman, Medine, p. 118; Koloğlu, Bedevi, pp. 96, 109.

${ }^{56}$ Suleiman Mousa, T.E. Lawrence: an Arab View, translated by Albert Butros, London, Oxford University Press, 1966, p. 16; Lawrence, Seven, p. 42; "The Hejas revolt is essentially a tribal movement and the Shereef a tribal chief who has thrown in his lot quite definitively with the tribesmen." PRO, FO 686/6, Report on the Hejas, (22.12.1916).

${ }^{57} \mathrm{PRO}, \mathrm{FO}$ 686/6, from Symes to $\mathrm{HC}$ in Cairo (No. 70/84-118), (05.08.1915).

58PRO, FO 141/462-1, from McMahon in Cairo to Edward Grey,

(11.09.1916). Those who joined the rebel forces were paid between four and ten English pounds per month. Brémond, Hedjaz, p. 87. 
propaganda on 26 June 1916, issuing a proclamation to the Islamic world in order to legitimise his actions against the Ottomans. ${ }^{59}$ In this proclamation, after complimenting the House of Osman and stating that the Emirs of Mecca were the first Muslim princes to acknowledge the Ottoman government, Husayn mentioned his service for the government over the past years while fighting with the Ottomans against rebellions in the region. Afterwards, he described how the Empire had become corrupt and decayed in the hands of the CUP and accused it of dragging the Empire into the war which brought pain and poverty to the last Islamic Empire of the world and particularly to the holy lands of Islam. He further accused the government of issuing a paper called İçtihad in which the biography of the Prophet was written in a very disrespectful manner; rejecting God's word: "the male must obtain the double of the female" and making them equal in inheritance; allowing the troops in the Mecca, Medina and Damascus garrisons to break their fasts during Ramadan; diminishing the power of the Ottoman Sultan by forbidding him even to choose for himself the chief of his personal cabinet; instructing the judge of the "Mohammaden Court of Mecca" to reject the evidence of believers outside the courts; hanging "at one time of 21 men among the learned Muslems and the Chiefs of Arabs" and deporting their innocent families to remote regions while confiscating their properties; digging up the tomb of "the Grand Emir and ascetic person" Al Sayyed al-Sharif "Abd al-Kader al-Jazairi al-Hassani and scattering his bones; and finally firing at the $\mathrm{K}$ 'abe and damaging its holy cover (qiswa).

It is known that the proclamation, before it was published in Cairo, had been amended slightly by the British, after the French had expressed their anxieties about the passages which condemned the Ottoman government for allowing troops to break their fasts and over the passage on evidence in the religious courts since France was also

${ }^{59}$ An English translation of this proclamation can be found in PRO, FO 141/461-3, from HC in Cairo to Edward Grey, (15.07.1916), (Attached report of Captain Cornwallis, Appendix-IV). For a French translation, see, André Mandelstam, Le Sort de L'Empire Ottoman, Lausanne, Libraire Payot, 1917, pp. 360-362. The information and quotes given in this paragraph referring the proclamation are all taken from PRO, FO 141/4613, from HC in Cairo to Edward Grey, (15.07.1916), (Attached report of Captain Cornwallis, Appendix-IV). 
exercising the same measures in its Muslim colonies. ${ }^{60}$ Rashid Rida, the editor of Al-Manar in Cairo also intended to make some amendments in order to give the proclamation a more nationalistic colour before its publication, however, Sharif has reportedly rejected and the original proclamation was published ${ }^{61}$ Obviously, the main aim of Sharif Husayn's proclamation was to justify the rebellion in the eyes of Muslims, most of whom were living under the British rule and most of whom had already condemned the Sharif for jeopardizing the holy lands of Islam. In this sense, the only passage that touched on the cause of Arabs was the execution of twenty one Arab notables, without even emphasizing their Arabist thoughts.

On 9 September 1916, Sharif issued his second proclamation in Al-Qibla newspaper, his official mouthpiece. ${ }^{62}$ This time, Husayn produced a more political argument against the policies of the CUP, though some religious points remained. Afterwards, the Sharif issued two more proclamations in November 1916 and March 1917 in AlQibla. ${ }^{63}$ In these proclamations, Sharif went on condemning the "wicked" actions of the CUP such as "plundering" the tomb of the Prophet in Medina, while making many references to his first two proclamations. ${ }^{64}$ It is also interesting that the word "Turanist" was employed by the Sharif in the last two proclamations while referring to the CUP. Considering the contexts of these proclamations, it can be said that this word was used by Husayn to denounce the actions of the CUP which were claimed to be in contradiction to the teachings of Islam, rather than to express a nationalist reaction to its "Turanist" policies.

${ }^{60} \mathrm{PRO}, \mathrm{FO} 141 / 461-3$, from FO to $\mathrm{HC}$ in Cairo (No. 594), (19.07.1916); Ibid., from the Residency in Cairo to FO, (20.07.1916).

${ }^{61}$ Ernest C. Dawn, "Ideological Influences in the Arab Revolt," in Dawn, From Ottomanism, p. 75.

${ }^{62} \mathrm{An}$ English translation of this proclamation can be found in PRO, $F O$ 141/462-1, from McMahon in Cairo to Edward Grey, (06.10.1916). See Mandelstam, Sort, pp. 363-364 for a French translation.

${ }^{63}$ For a French translation of the third proclamation, see "Le Réveil Arabe au Hedjaz," Revue de Monde Musulman, Vol. 47, 1921, pp. 14-23. For French translation of the fourth proclamation, see Mandelstam, Sort, pp. 392-393.

${ }^{64}$ Mandelstam, Sort, p. 392. 
4.

Once the revolt broke out in the summer of 1916, the Ottomans followed a policy, on the one hand, of bribery among the Bedouins and of countering the religious propaganda used by Sharif Husayn, and, on the other, of denial of any "Arab" nature of the revolt. Throughout the revolt, the Ottomans provided grain and gold to ensure the loyalty of the Bedouins. In a letter to the Commandant of Yanbo, intercepted and forwarded by the Sharifian forces to the British, the muhafiz of Medina Basri Paşa stated that "large amount of gold and decorations have been given Arabs round Medina to bribe them and telling commandant to do likewise" in Yanbo. 65 In September 1916, the government decided to sell wheat, that was brought to Hijaz by trains, for half of its real cost to the Hijazi Bedouins who were still loyal to the Ottomans. ${ }^{66}$ Naci Kâşif relates that the loyalty of the tribesmen along the Hijaz Railway up to Medina was to a great extent maintained thanks to the utilization of train wagons in distribution of the grains to the Bedouins. The situation, however, was not the same between Mecca and Medina due to the absence of a railway on this line. ${ }^{67}$

The Ottoman government also awarded medals to the Bedouin shaykhs, again in an attempt to ensure their allegiance. In August 1916, Cemal Paşa proposed the Ministry of the Interior to award Ottoman medals to Hamid Abu Shamar from the Beli tribes, Nuri alShalan from the Ruwala tribes, and some of their relatives because of their loyalties to the government after the outbreak of the Hijaz Revolt. 68

Apart from the use of money, foodstuffs and medals to ensure the loyalty of the Bedouins, the Ottoman government also attempted to counter the religious propaganda used by Sharif Husayn at the beginning of the revolt. Shortly after the outbreak of the revolt, the Ottomans, on 1 July 1916, appointed Sharif Husayn's rival, Sharif

${ }^{65} \mathrm{PRO}, \mathrm{FO} 141 / 461-3$, from Wilson in Jidda to Arab Bureau in Cairo, (04.08.1916).

${ }^{66}$ Başbakanlık Osmanlı Arşivi (BOA), DH.EUM.4.Şb, 203/38, (17.09.1916).

${ }^{67} \mathrm{~K} 1 \mathrm{c}$ man, Medine, p. 80.

${ }^{68}$ BOA, DH.KMS., 41/43, (19.08.1916). 
'Ali Haydar, as the new Emir of Mecca. ${ }^{69}$ On 9 August 1916, fourteen days after his arrival in Medina, Sharif 'Ali Haydar issued his counter-proclamation, in which he denounced the actions of Sharif Husayn and justified the policies of the Ottoman government from a religious as well as a political perspective. ${ }^{70}$

The Ottoman government did not make the news of revolt public for more than a month after it had broken out. Then, on 26 July 1916 an article called "Intrigue in Mecca" (Mekke'deki Fesat) appeared in Tanin newspaper, the unofficial mouthpiece of the CUP. This article reflects the main argument of the CUP against the rebellion of Sharif Husayn that this revolt was not representative of the Arab population as a whole and that, contrary to any such idea, there was no Turkish - Arab division, the Turks and Arabs being united as members of the Ottoman Empire. Accordingly, it is also claimed that neither Arabism nor Islamism was concerned in the revolt, and that the sources of the intrigue in the Hijaz were personal aspirations of Husayn and "the joining to Husayn of some vagabond tribesmen of whom the main livelihood had always been pillage."71 Moreover, according to the article, Britain was "deceived by the spurious influence of Sharif Husayn" and plotted this revolt with gold. ${ }^{72}$ Finally, it is claimed that although the government was aware of the real intentions of Sharif Husayn for a long time, it did not take any actions mainly because there were more important issues to be dealt with and also because the government thought that Husayn's ambitions for kingship, that had been "burning his heart" for quite a long time, could be extinguished by good management. ${ }^{73}$

Towards the end of the war, the Ottoman government, deeply concerned about the struggle against the rebels, attempted to arrange

${ }^{69}$ Tanin, 02.07 .1916 , p. 1 . Since 1840 , there was a rivalry between two clans of the House of Hashem: Dhawu-'Awn and Dhawu-Zayd. Sharif Husayn was a member of the former, while his rival, Sharif 'Ali Haydar was a member of the latter.

${ }^{70}$ The full text of the original proclamation can be found in Tanin, 05.09.1916, pp. 1-2. For an English translation, see PRO, FO 686/11, Sherif Haydar's Proclamation, (09.08.1916).

${ }^{71}$ Tanin, 26.07.1916, p. 1.

${ }^{72}$ Idem. .

${ }^{73}$ Idem. 
a peace with Sharif Husayn. After the Soviet government published the infamous Sykes-Picot Agreement in November 1917 and the imperialist intentions of the British and the French governments over the Middle East were revealed, Cemal Paşa decided to use this revelation to propose a peace to the Sharifs. On 13 November 1917, he wrote letters to Sharif Faysal and to Ja'far al-'Askari, the Chief of General Staff of the revolting army. In his letter to Faysal, Cemal stated that Sykes-Picot Agreement was in contradiction with the independence aims of the Arabs and proposed to reopen negotiations "with a view to solve the problem in favour of Islam." 74 In the other letter, Cemal reminded to Ja"far that "General Allenby is to-day conquering Palestine which Salabidden Eyoubi [referring to Salah alDin Ayyubi] defended" and proposed to see him in person in Damascus assuring that he would be allowed to return in safety. ${ }^{75}$ Faysal, instructed by his father and the British, did not give an official reply to Cemal, though unofficially send him the message that sword was the intermediary between them. Although the new commander of the Fourth Army, Muhammed Cemal Paşa made three more peace proposals to Faysal in February, June and August 1918, he too did not get any positive replies. ${ }^{76}$

\section{Conclusion}

The Ottomans were among the losers of the Great War. By 1918, they were totally defeated by the British and the Sharifian forces in southern fronts. The result of this defeat was the termination of the nearly 400 year old Ottoman-Turkish rule over the Arab lands, and thus, opening of a new phase in Turkish - Arab relations. Shortly after the end of the war, by early 1920's, the new rulers of the Arab Middle East completed the partition of the region in accordance with the arrangements which had been done during and after the war, such as Sykes-Picot Agreement (1916), Balfour Declaration (1917) and San Remo Conference (1920). Eventually, Syria and Lebanon became

${ }^{74} \mathrm{PRO}$, FO 141/431-3, from HC in Cairo to James Balfour (No. 316), (25.12.1917), (Attached letter from Cemal to Faysal).

${ }^{75} \mathrm{Ibid}$., (Attached letter from Cemal to Ja 'far).

${ }^{76} \mathrm{Ibid}$., from the Residency in Cairo to James Balfour (No. 70), (08.04.1918); Ibid., from Wilson in Jidda to Arab Bureau in Cairo (No. W 158/164), (07.06.1918); Tauber, World, pp. 154-156. 
French mandates, while the British established mandate regimes over Palestine, Transjordan and Iraq. The Hijaz, however, remained as an independent country under the kingship of the Sharifian family until their disposal by Saudis in 1925 .

As can be seen, Britain's war-time commitments to the Sharifian family were in great contradiction with her actual designs in the Middle East. Nevertheless, the Sharifian family continued to be a part of British strategies in the region as in 1921 Sharif Abdullah became the king of the British Mandate of Transjordan, and Sharif Faysal, who had been expelled from Syria by the French, became the king of the British Mandate of Iraq. ${ }^{77}$ Therefore, here we come to the conclusion that by the first quarter of the $20^{\text {th }}$ century, the British took advantage of the Sharifian family as an agent to instigate, conquer and finally to control the Arab Middle East. While the Ottomans were striving to counter the revolt by dispensing gold, grain and medals, they were actually contending with the British who provided the Sharifan family with gold, grain and arms. Under these conditions, one can argue that Ottoman - Arab relations in the Hijaz during the war developed as a matter of struggle between two hostile states, who were Britain and the Ottoman Empire, to win over local tribes and leaders by bribery and propaganda. In the end, it was the British (via the Sharifian family) who secured the support of the majority of the local tribes and leaders, and drove them against the Ottomans.

To conclude, Sharif Husayn's ambitions for independence combined with British imperialist designs in the Middle East and produced the Hijaz Revolt during the very crucial years of the Great War. Therefore, as a partial confirmation of the article that appeared in Tanin on 26 July 1916, it can be argued that reasons behind the revolt were in fact economic and political rather than religious or nationalistic. However, Husayn's religious constraints in the holy lands of Islam compelled him and his sons to employ a more religious language to carry out and justify their actions. ${ }^{78}$ While the Ottoman

${ }^{77}$ At present, the rule of the Hashemite dynasty continues only in the Hashemite Kingdom of Jordan.

${ }^{78}$ Before starting his actions, the Sharif's main concern was religious. He was afraid of being condemned by the Islamic world because he rose against the caliphate. He several times expressed these concerns to the British. PRO, FO 141/461-1, from Governor General in Khartoum to Clayton in 
policy shifted from firm centralization to attempted conciliation, then to failure to respond to the growing threat of revolt effectively, and finally to unsuccessful bids for peace, Sharif Husayn's policy moved from somewhat unconvincing accommodation to outright rebellion. In the end, although it succeeded in driving off the Ottomans from the Arab lands and thus opening a new phase in the course of Turkish Arab relations, the revolt of Sharif Husayn does not represent an overwhelming expression of Arab sentiment against the Ottomans. It was rather a local reaction which took advantage of the general state of the war and the conciliatory policies of the centre, and which exceeded its natural limits of success thanks to the support of a Great Power. This, however, does not change the fact that the revolt remains to be a traumatic moment in the social memory of the Turkish people since it has long been used and is still being used by Turkish elites as an instrument to strengthen their nationalist and secularist discourse.

Cairo (No. 721), (05.10.1915); Ibid., précis of the account of his visit and mission to Sharif Husayn ibn "Ali of Mecca by the messenger "A", (05.10.1915). 'Abdallah states the importance of the religion in their actions as: "(...) religion which justifies it [the revolt] and which is the sole foundation of action prevents us from working at once." PRO, FO 141/460-8, from Consul-General in Cairo to FO (No.303), (10.12.1914), (Attached letter from 'Abdallah). 